\title{
From soil to plant, the journey of P through trophic relationships and ectomycorrhizal association
}

\author{
Adeline Becquer ${ }^{1}$, Jean Trap ${ }^{2}$, Usman Irshad ${ }^{3}$, Muhammad A. Ali ${ }^{4}$ and Plassard Claude ${ }^{*}$ \\ ${ }^{1}$ UMR Eco\&Sols, Institut National de la Recherche Agronomique, Montpellier, France \\ ${ }^{2}$ UMR Eco\&Sols, Institut de Recherche pour le Développement, Montpellier, France \\ ${ }^{3}$ Department of Environmental Sciences, COMSATS Institute of Information Technology, Abbottabad, Pakistan \\ ${ }^{4}$ Department of Soil Science, Bahauddin Zakariya University, Multan, Pakistan
}

\section{Edited by:}

Pierre-Emmanuel Courty, University of Basel, Switzerland

\section{Reviewed by:}

Kate Warpeha, University of Illinois at Chicago, USA

Wayne Versaw, Texas A\&M University, USA

\section{*Correspondence:}

Plassard Claude, UMR Eco\&Sols, Institut National de la Recherche Agronomique, 2 place Pierre Viala, 34060 Montpellier Cedex 1, France e-mail: plassard@supagro.inra.fr
Phosphorus $(\mathrm{P})$ is essential for plant growth and productivity. It is one of the most limiting macronutrients in soil because it is mainly present as unavailable, bound $\mathrm{P}$ whereas plants can only use unbound, inorganic phosphate (Pi), which is found in very low concentrations in soil solution. Some ectomycorrhizal fungi are able to release organic compounds (organic anions or phosphatases) to mobilize unavailable P. Recent studies suggest that bacteria play a major role in the mineralization of nutrients such as $P$ through trophic relationships as they can produce specific phosphatases such as phytases to degrade phytate, the main form of soil organic P. Bacteria are also more effective than other microorganisms or plants at immobilizing free Pi. Therefore, bacterial grazing by grazers, such as nematodes, could release Pi locked in bacterial biomass. Free Pi may be taken up by ectomycorrhizal fungus by specific phosphate transporters and transferred to the plant by mechanisms that have not yet been identified. This mini-review aims to follow the phosphate pathway to understand the ecological and molecular mechanisms responsible for transfer of phosphate from the soil to the plant, to improve plant P nutrition.

Keywords: phosphate, tree $\mathrm{P}$ nutrition, bacterial grazers, ectomycorrhizal association, phosphate transport systems

\section{INTRODUCTION}

Phosphorus (P) is an essential element for plant growth and productivity. $\mathrm{P}$ is a component of nucleic acids, phospholipids, and ATP and, as such, is involved in controlling enzyme reactions and the regulation of the metabolic pathway (Schachtman, 1998; Raghothama, 1999; Vance et al., 2003). Plants can only take up $\mathrm{P}$ as free phosphate ions, $\mathrm{H}_{2} \mathrm{PO}_{4}{ }^{-}$and $\mathrm{HPO}_{4}{ }^{2-}(\mathrm{Pi})$. However, concentrations of free $\mathrm{Pi}$ in soil solution are generally low, around 1-10 $\mu \mathrm{M}$ (Hinsinger, 2001), owing to its strong affinity for combining with cations and clays, leading to the formation of insoluble P complexes that are unavailable for plants (Hinsinger, 2001). $P$ is, therefore, one of the most limiting macronutrients for plant growth (Raghothama, 1999) and productivity (Batjes, 1997) in many terrestrial ecosystems. However, plants are involved in complex ecological interactions, especially through symbiotic mycorrhizal association, allowing them to meet their $\mathrm{P}$ requirements (Bucher, 2007; Javot etal., 2007; Lambers etal., 2008; Plassard and Dell, 2010).

In forest ecosystems, particularly in temperate and boreal biomes, $95 \%$ of trees establish a mutualistic ectomycorrhizal (ECM) symbiosis with fungal symbionts (Smith and Read, 2008). The ECM fungus forms a soil-fungus interface outside the roots of the host plant with a hyphal sheath around short lateral roots and extra-radical hyphae growing from the sheath. The hyphae explore a large volume of soil not accessible to roots and allow the translocation of nutrients and water to the host plant in exchange for sugar (Nehls et al., 2010). The nutritional exchanges between fungus and host occur in the Hartig net located at the interface between the root cortical cells and the fungal hyphae. The formation of symbiotic structures with ECM fungi is considered to be the most widespread means of increasing $\mathrm{P}$ acquisition by trees (Chalot et al., 2002; Torres Aquino and Plassard, 2004; Smith and Read, 2008).

This mini-review considers the outward journey of $\mathrm{P}$, from soil to tree through ECM association. It discusses the mechanisms by which the fungus mobilizes poorly available organic $\mathrm{P}(\mathrm{Po})$ sources such as phytate and takes up Pi at the soil-fungus interface. It then summarizes current knowledge of the fungus-plant interface and suggests hypotheses concerning the transfer of $\mathrm{P}$ from the fungus to the plant.

\section{ROLE OF ECTOMYCORRHIZAL FUNGI AT THE SOIL-FUNGUS INTERFACE ECM AND PHYTATE MOBILIZATION}

A large proportion of $\mathrm{P}$ in forest soils is found as Po compounds (Tibbett, 2002). Most Po is in the form of phosphate esters (C-O$\mathrm{P}$ bonds) such as phosphate monoesters (e.g., sugar-phosphates) and phosphate diesters (nucleic acids and phospholipids; Turner, 2008). Rennenberg and Herschbach (2013) suggested that ECM fungi might absorb Po as a whole molecule. The identification of three genes encoding glycerophosphoinositol transporters in the Hebeloma cylindrosporum genome (JGI project list) supports this hypothesis but the activity of these transporters has not yet been established. Furthermore, it is generally accepted that, in order to be used by plants and microorganisms, phosphate groups must be released from the ester bond by phosphatase 
enzymes (Plassard and Dell, 2010). Of soil Po compounds, phytate (myo-inositol hexakisphosphate), a form of inositol phosphate, is particularly interesting as a potential source of $\mathrm{P}$ for plants, because it is found in many ecosystems, including forest ecosystems (Turner etal., 2002). Phytate is a form of $\mathrm{P}$ reserve in seeds (Raboy, 2007) and it is hydrolyzed during germination by intracellular plant phytases to supply Pi to young seedlings. However, if the seeds do not germinate, their phytate content will fill the pool of soil phytate (Figure 1). To be used by plants and microorganisms, phosphate groups of phytate must be released by specialized enzymes (phytases). The efficiency of organisms in mobilizing phytate in the soil solution relies on their ability to produce phytases in the external medium or at least in the cell wall space. To date, plants grown in axenic conditions have been shown to have very poor capacity to use phytate as the sole source of P (Hayes et al., 2000; Richardson et al., 2000, 2001a,b), suggesting that they have little or no capacity for releasing phytase into the external medium (Figure 1). The capacity of ECM fungi to release phytase is still a matter of debate: some studies have reported that ECM basidiomycetes have a high capacity (Antibus etal., 1992; McElhinney and Mitchell, 1993), no capacity (Mousain et al., 1988) or a very low capacity (Mousain etal., 1988; Louche etal., 2010) to produce phytase in axenic cultures.

Current knowledge suggests that ECM fungi on their own are not the best symbionts for improving plant nutrition using phytate as the sole source of P (Richardson et al., 2007; Plassard et al., 2011; Figure 1A). Another strategy that has been little studied until now relies on the exploitation of the interactions between plants, ECM fungi, bacteria, and their grazers within the rhizosphere (food web relationships) combined with the capacity of bacteria to degrade phytate (Figure 1B).

\section{ROLES OF RHIZOSPHERE TROPHIC INTERACTIONS}

Unlike ECM fungi, bacteria inhabiting the plant rhizosphere are able to mineralize phytate in vitro (Jorquera et al., 2008a,b; Maougal et al., 2014). Several studies have shown that inoculating plants with these bacteria, in sterile conditions, improves plant access to P from phytate (Richardson and Hadobas, 1997; Hayes et al., 2000; Richardson et al., 2001b). While the plants provide carbon, the bacteria mineralize Po and increase the available $\mathrm{P}$ pool. However, bacteria are more competitive than plants and ectomycorrhizal fungi to take up $\mathrm{P}$ released by phytase (Irshad et al., 2012). In consequence, a large fraction of $\mathrm{P}$ released from phytate is immobilized and locked in the soil bacterial biomass (Figure 1A). It could, therefore, be possible that bacterial grazers significantly improve plant $\mathrm{P}$ nutrition through re-mineralization of the microbial P pool (soil microbial loop), and reduction of the competition between plants and bacteria for Pi (Clarholm, 1985; Figure 1B). Nevertheless, studies focusing on protozoa (Coleman et al., 1977; Cole et al., 1978; Griffiths, 1986; Darbyshire et al., 1994; Bonkowski etal., 2001) and nematodes (Anderson et al., 1978; Griffiths, 1986; Bardgett and Chan, 1999; Irshad et al., 2011, 2012) reported that bacterial grazers have either no effect (Griffiths, 1986), a short-term increase (Anderson et al., 1978; Darbyshire et al., 1994; Djigal etal., 2004) or a significant increase (Coleman et al., 1977; Cole et al., 1978) on soil P mineralization with obvious consequences on plant P nutrition (Herdler et al., 2008;

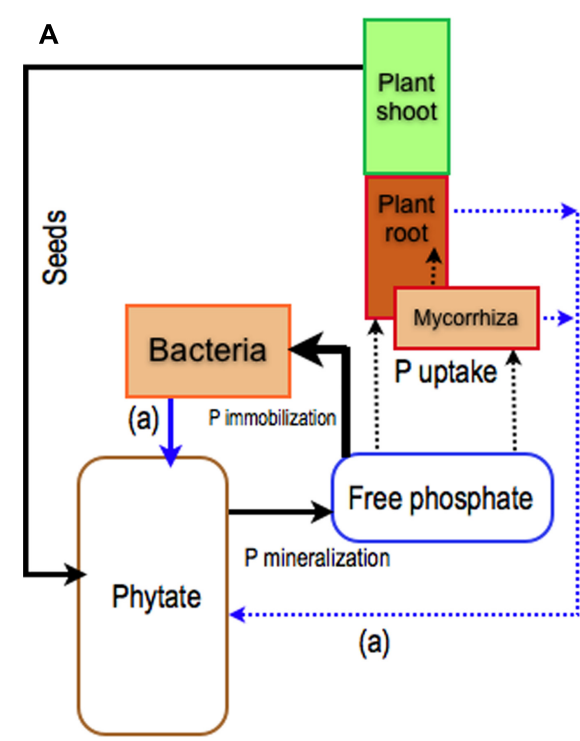

FIGURE 1 | Role of plants and their mycorrhizal symbionts together with rhizosphere bacterial populations on the use of soil phytate. Phytate is the main pool of organic phosphorus (Po) in soil (Turner et al., 2002) that is filled by phytate from ungerminated seeds. To be used by plants, phytate must be hydrolyzed by specialized enzymes called phytases. (A) The capacity of roots and ECM fungi to release phytases in the rhizosphere is very low (Richardson et al., 2007) whereas some bacteria have a great ability to

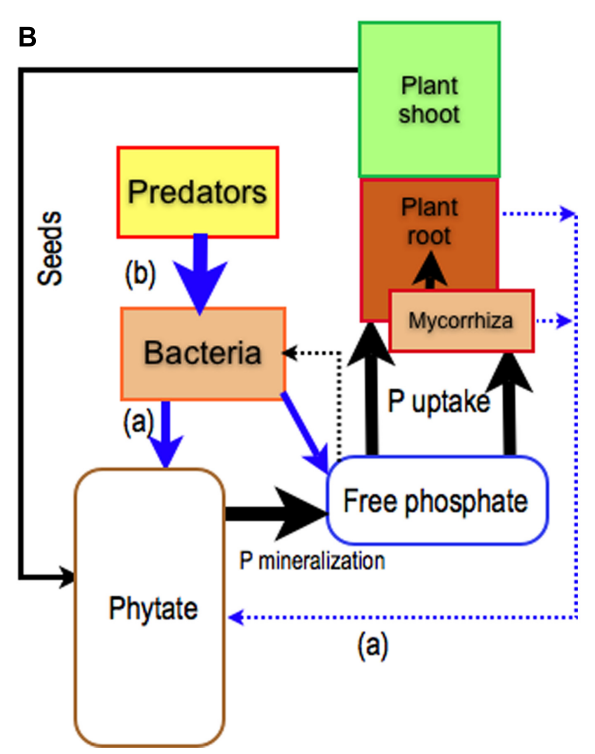

produce phytase and to mineralize phytate (Jorquera et al., 2008a,b) for their own. This will result in bacterial $P$ immobilization at the expense of plants and ECM fungi. (B) To improve $P$ nutrition of plants alone or with ECM fungi, $P$ from phytate locked in bacteria has to be released through the grazing activity of microfauna, such as bacterial grazer nematodes (Irshad et al., 2012). Black arrows: P fluxes, blue arrows: biological controls, (a) release of phytase, (b) grazing activity. 
Irshad etal., 2012). These contradictory results were put forward without any clear identification of the ecological factors driving the efficiency of bactivorous-induced $\mathrm{P}$ mineralization. More specifically, the study carried out by Irshad et al. (2012), with phytate as the sole source of $\mathrm{P}$, showed that the presence of both bacterial-feeder nematodes (Rhabditis sp.) and Bacillus subtilis increased the net amount of $\mathrm{P}$ in Pinus pinaster seedlings (Figure 1B). A possible mechanism involved in these patterns lies in the ability of grazers to increase bacterial metabolism and, probably, phytase production (Figure 1B). It would, therefore, be interesting to study the expression of two main classes of bacterial phytase genes, the histidine acid phytases (HAP), and the $\beta$-Propeller phytase (BPP) (Mullaney and Ullah, 2003) when bacteria are in the presence of their grazers. It may be supposed that predation has two synergistic effects; (i) grazers may cause the overexpression of bacterial HAP and/or BPP and increase the mineralization of phytate and (ii) grazers may increase phosphate availability by the release of $\mathrm{P}$ from the microbial biomass (Figure 1B).

However, it is not clear how the presence of ECM fungi affects this positive trophic $\mathrm{P}$ pathway. The experimental study conducted by Irshad et al. (2012) with P. pinaster showed that the presence of the ECM fungi ( $H$. cylindrosporum) did not alter the positive trophic effect on plant $P$ nutrition from phytate. This was probably due to experimental conditions used by the authors, which used agarose medium rather than soil. ECM fungi could be expected to have a positive effect by increasing the soluble mineral $\mathrm{P}$ uptake by the host from the additional $\mathrm{P}$ released by nematodes and subsequently locked in the soil matrix (Plassard and Dell, 2010). The role of ECM fungi remains unclear and further studies are clearly needed.

\section{ECM AND INORGANIC PHOSPHORUS ACQUISITION}

After mineralization of phytate and other Po compounds, the phosphate released must be absorbed by plants and mainly by ECM fungi, which are more efficient than the roots. Van Tichelen and Colpaert (2000) showed that ECM fungi significantly increased the phosphate uptake capacity of pine roots. As discussed above, the mycorrhizal basidiomycete produces an extraradical mycelium that is able to explore the soil away from the root, significantly increasing the volume of soil exploited by plants with ECM fungi. It has been shown that such exploration was responsible for the major fraction of $\mathrm{P}$ uptake by plants (Torres Aquino and Plassard, 2004).

The acquisition of free phosphate by ECM fungi occurs through a plasma membrane phosphate transporter (Figure 2A). The first putative Pi transporter gene from an ECM fungal species (Kothe et al., 2002) was identified based on homology with the yeast Pi transporter PHO84 (Bun-ya etal., 1991). More recently, many others have been found in the genomes of five ECM fungi (JGI Genome Portal, Casieri et al., 2013). Most ECM fungi have three to five putative phosphate transporter genes that belong to the Pht1 subfamily (Karandashov and Bucher, 2005; phosphate/ $\mathrm{H}^{+}$ transporters). However, the phosphate transporter encoded by the TmPT3 gene was classified as a phosphate/ $\mathrm{Na}^{+}$transporter $(\mathrm{Pht} 2)$. This type of transporter has first been identified in the yeast, Saccharomyces cerevisiae (Martinez and Persson, 1998). These results

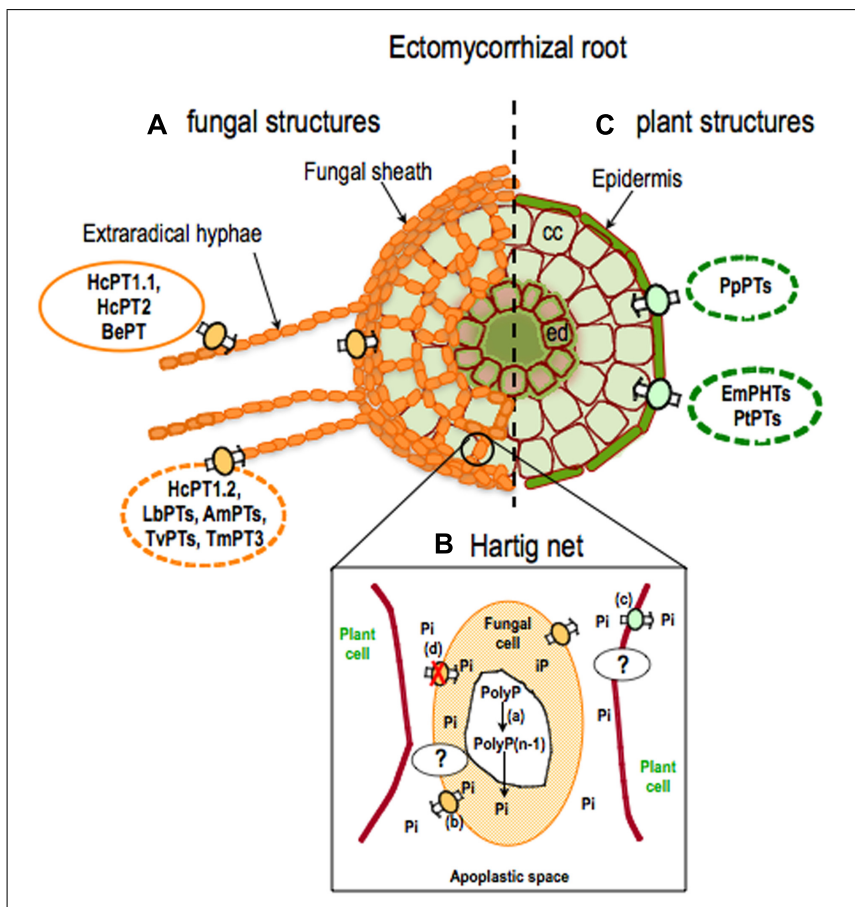

FIGURE 2 | Current knowledge about phosphate transporters in ectomycorrhizal roots. In ectomycorrhizal (ECM) roots, the fungus forms extraradical hyphae and a fungal sheath outside the root (A) and the Hartig net surrounding root cells (B) hiding epidermal cells and cortical (cc) cells (C). (A) In fungal cells, the uptake of Pi occurs mostly through Pht1 phosphate transporters. To date, only HCPT1.1, HCPT2 (Tatry etal., 2009), and BePT (Wang etal., 2014) genes have been characterized by heterologous expression in yeasts. Genomics and transcriptomic data suggest that other transporters may play a role in phosphate uptake (e.g., HcPT1.2, LbPTs, AmPTs, TvPTs, TmPT3 (Pht2; Casieri et al., 2013). (B) In the Hartig net, fungal and plant cells have a common apoplastic space with no direct symplastic communication. It is hypothesized that the hydrolysis (a) of polyphosphate (PolyP) increases Pi concentration in the cytosol of the fungus. Up to now, the molecular mechanisms sustaining $P$ efflux from the fungus (b) to the apoplast and P influx (c) from the apoplast to the plant cell have not been identified. It is also hypothesized that fungal $P$ transporters may not be functioning (d). (C) In plant cells, phosphate ions enter through plant $\mathrm{P}$ transporters. Little is known about plant transporters responsible for $\mathrm{Pi}$ acquisition in ECM roots. Only phosphate transporters from Populus trichocarpa (PtPTs; Loth-Pereda et al., 2011) and Eucalyptus marginata (EmPhts; Kariman et al., 2014) have so far been identified. Transcriptomic data for Pinus pinaster (Canales et al., 2013) showed putative encoding sequences for phosphate transporters (PpPTs). Full lines indicate transport systems whose capability in phosphate transport has been verified by heterologous expression in yeast. Dotted lines indicate transport systems whose involvement in phosphate transport during mycorrhizal symbioses is suggested by genomic or transcriptomic data. ed: endodermal cells. Hc: Hebeloma cylindrosporum, Be: Boletus edulis, Tm: Tuber melanosporum, Am: Amanita muscaria, Lb: Laccaria bicolor, Tv: Tricholoma vaccinum, Pt: Populus trichocarpa, Em: Eucalyptus marginata, Pp: Pinus pinaster.

suggest that the efficiency of phosphate uptake into ECM fungal cells could rely mostly upon the external $\mathrm{pH}$. Of all phosphate transporters so far identified in ECM fungi, only HcPT1.1, HcPT2, and BePT have been characterized by heterologous expression in yeast (Tatry et al., 2009; Wang et al., 2014). HcPT1.1 and HcPT2 were expressed in $H$. cylindrosporum alone or associated with its natural host plant, $P$. pinaster, grown in low or high $\mathrm{P}$ conditions. However, the transporters respond in different ways to the 
external Pi concentration. HcPT1.1 transcripts were up-regulated in fungal cells exposed to phosphate starvation in solution or to low phosphate availability in soil such as phosphate transporters of the ECM fungus Tricholoma spp. (Kothe et al., 2002) and Boletus edulis (Wang et al., 2014), whereas the transcripts levels of HcPT2 were less dependent on the external P concentration (Tatry et al., 2009). The expression patterns of these two transporters (Tatry et al., 2009) and the immunolocalization of HcPT1.1 (Garcia et al., 2013) indicate that they are found in extraradical hyphae (Figure 2). H. cylindrosporum might use HcPT1.1 to mediate Pi uptake in phosphate starvation conditions and $\mathrm{HcPT} 2$ when soil $\mathrm{P}$ availability is high (Tatry et al., 2009).

\section{PHOSPHATE TRANSLOCATION FROM THE EXTRAMATRICIAL MYCELIA TO THE HARTIG NET}

Once absorbed, $\mathrm{P}$ is transferred via the extra-radical mycelium to the ECM roots. This has been demonstrated using ${ }^{32} \mathrm{P}$ labeling and pulse chase experiments in simple laboratory systems where the distance of translocation did not exceed $40 \mathrm{~cm}$ (Finlay and Read, 1986; Timonen et al., 1996). For forests, it is accepted that this range can be much higher (Anderson and Cairney, 2007). The first studies on $\mathrm{P}$ translocation reported that ECM hyphae contain a tubular vacuole system (Ashford and Allaway, 2002). Although there is no direct evidence that these vacuoles interconnected by smaller membrane tubules could be involved in $\mathrm{P}$ transport, Ashford and Allaway (2002) showed movement of fluorescent probes in this vacuolar system and that ECM fungal vacuoles hold substantial amounts of $\mathrm{P}$ mainly in the form of polyphosphates. In parallel, mathematical models suggested that this network was only responsible for short distance P translocation at the $\mathrm{mm}$ to $\mathrm{cm}$ scale (Darrah et al., 2006; Fricker et al., 2008). Other mechanisms could be involved in longer distance transport but there is still little evidence of this (Cairney, 2011).

\section{UNDERSTANDING THE FUNGUS-PLANT INTERFACE FROM THE FUNGAL CELL TO THE HOST CELL}

Interactions between ECM fungi and plants are based on the bidirectional transfer of carbohydrates and nutrients, such as $\mathrm{P}$, across an interface (Bücking and Heyser, 2001). For a long time, studies have demonstrated the transfer of $\mathrm{P}$, mainly as inorganic orthophosphate, from the ECM fungus to the plant (Harley and Loughman, 1963; Skinner and Bowen, 1974; Finlay and Read, 1986). Bücking and Heyser (2001) showed, by microautoradiographic studies following ${ }^{33} \mathrm{P}$, that $\mathrm{Pi}$ accumulated rapidly in the ECM sheath and was slowly translocated off the Hartig net to the cortical cells. Because there is no direct symplastic continuity between the ECM fungus and the roots, Pi has to move into the interfacial apoplast before it can be absorbed by the plant (Peterson and Bonfante, 1994; Figure 2B). The molecular mechanisms of Pi transport across the mycorrhizal interface have not yet been determined for mycorrhizal symbioses (Harrison, 1999; Plassard and Dell, 2010; Smith and Smith, 2011; Figure 2B).

Nutrient transfer models generally involve (1) the passive efflux of phosphate and carbohydrates through the fungal and plant plasma membranes into the interfacial apoplasm and (2) the active absorption of nutrients by both symbionts driven by an $\mathrm{H}^{+}$. ATPase (Smith and Smith, 2011). However, the net loss of P from
ECM fungi in pure culture is normally regarded as slight (Cairney and Smith, 1993a). There must be specific conditions favoring the efflux of phosphate from the fungus at the fungus-root interface in ectomycorrhizas in order to ensure that the transfer of $\mathrm{P}$ is sufficiently large to meet the host plant demand (Smith and Smith, 2011). It has been suggested that passive Pi flux across the fungal plasma membrane is due to low Pi concentration in the apoplast at the fungus-root interface relative to the cytoplasm (Smith et al., 1994). As suggested for arbuscular mycorrhizal (AM) associations (Solaiman and Saito, 2001), this gradient could be the result of polyphosphate degradation in the fungal cytosol (Clarkson, 1985) and the efficient phosphate uptake across the plant plasma membrane through phosphate transporters (Bucher, 2007; Javot et al., 2007). Moreover, P efflux from free-living mycelia of ECM fungi has been shown to be clearly affected by an extracellular supply of cations, particularly $\mathrm{K}^{+}$and $\mathrm{Na}^{+}$and carbohydrates (Cairney and Smith, 1993b; Bücking, 2004). While these observations are derived from mycelia in axenic culture, they provide strong indirect evidence that the efflux may be influenced by the chemical environment of the zone of exchange localized in the Hartig net.

Alternatively, the output of Pi from the ECM fungus toward the common apoplasm could be an active mechanism involving phosphate transporters whose presence and/or activity is regulated, at least partly, by host demand (Cairney and Smith, 1992). Genome sequencing of $H$. cylindrosporum has identified three phosphate transporters which have been characterized in yeast as phosphate influx transporters (Tatry et al., 2009). Phosphate efflux could be provided by one of these carriers, able to input and output Pi depending on specific conditions. The yeast high affinity phosphate transporter (PHO84) is able to transport phosphate bidirectionally, depending on the $\mathrm{pH}$ gradient across the plasma membrane (Fristedt et al., 1996). The phosphate efflux could also be mediated by another transport system, as yet unidentified, specifically responsible for phosphate efflux at the fungus-root interface (Figure 2B).

\section{THE RELEASE OF P TO THE PLANT}

Contrary to AM symbiosis (see Bucher, 2007 for review), little is still known about plant transporters responsible for Pi acquisition in the Hartig net of roots with ECM fungi (Figure 2B). The studies by Loth-Pereda et al. (2011) and Kariman et al. (2014) are the first to provide details of the regulation of plant gene expression that may be involved in phosphate uptake by root cells (Figures 2B,C). Loth-Pereda et al. (2011) showed that Populus colonization by both AM and ECM fungi led to the up-regulation of two Pht1 transporters, PtPT9, and PtPT12. These genes are also up-regulated in Pi-depleted media. This suggests that these two genes could be involved in plant Pi uptake in the Hartig net (Figure 2B) and/or in $\mathrm{Pi}$ acquisition from soil solution (Figure 2C). Other plant Pht1 gene products were down-regulated in ECM symbiosis (Loth-Pereda etal., 2011; Kariman et al., 2014; Figure 2C). This will probably result in a reduction in $\mathrm{Pi}$ absorption via the direct (root) pathway toward a mycorrhizal pathway as documented for AM symbiosis (Smith and Smith, 2011). However, it is not still clear whether the reduced expression of $P h t 1$ genes in mycorrhizal roots is triggered by improved $\mathrm{P}$ nutrition of plants 
or whether it is a symbiotic response (Javot et al., 2007). Furthermore, no Pht1 genes are specifically induced during ECM development as observed in AM symbiosis in woody plants (LothPereda et al., 2011) and herbaceous species (Harrison et al., 2002; Bucher, 2007).

\section{CONCLUSION}

The molecular mechanisms sustaining P fluxes from ECM fungi to root cells in the Hartig net have not yet been explained. This lack of knowledge limits our ability to improve P-utilization efficiency in forest ecosystems. Large scale sequencing of fungal (Martin et al., 2011) and tree (Mackay etal., 2012) genomes will provide candidate genes that may be involved in these $\mathrm{P}$ exchanges. Using the genetic transformation methods available for ECM fungi (Combier et al., 2003; Kemppainen et al., 2005; Rodríguez-Tovar et al., 2005; Garcia et al., 2014) and trees (e.g., P. pinaster, Alvarez and Ordás, 2013) it will then be possible to study these candidates and determine their actual role in ECM symbiosis.

\section{ACKNOWLEDGMENTS}

This work was supported by the ANR project "TRANSMUT" (2010 BLAN 1604.03) and "UNLOCKP” (ANR 11 BSV7 015 01). Adeline Becquer is being funded by a fellowship (Contrat Jeune Scientifique) from INRA. We are grateful to F. Martin and the Mycorrhizal Genomics Initiative consortium for access to unpublished genome data. The genome sequence data were produced by the U.S. Department of Energy Joint Genome Institute in collaboration with the user community. The JGI is supported by the Office of Science of the U.S. Department of Energy under Contract No. DE-AC02-05CH11231.

\section{REFERENCES}

Alvarez, J. M., and Ordás, R. J. (2013). Stable Agrobacterium-mediated transformation of maritime pine based on kanamycin selection. ScientificWorldJournal 2013, 681792. doi: 10.1155/2013/681792

Anderson, I. C., and Cairney, J. W. G. (2007). Ectomycorrhizal fungi: exploring the mycelial frontier. FEMS Microbiol. Rev. 31, 388-406. doi: 10.1111/j.15746976.2007.00073.x

Anderson, R. V., Coleman, D. C., Cole, C. V., and Elliott, E. T. (1978). Effect of the nematodes Acrobeloides sp. and Mesodiplogaster lheritieri on substrate utilization and nitrogen and phosphorus mineralization in soil. Ecology 62, 549-555. doi: $10.2307 / 1937720$

Antibus, R. K., Sinsabaugh, R. L., and Linkins, A. E. (1992). Phosphatase activities and phosphorus uptake from inositol phosphate by ectomycorrhizal fungi. Can. J. Bot. 70, 794-801. doi: 10.1139/b92-101

Ashford, A. E., and Allaway, W. G. (2002). The role of the motile tubular system in mycorrhizal fungi. Plant Soil 244, 177-187. doi: 10.1023/A:1020271121683

Bardgett, R. D., and Chan, K. F. (1999). Experimental evidence that soil fauna enhance nutrient mineralization and plant nutrient uptake in montane grassland ecosystems. Soil Biol. Biochem. 31, 1007-1014. doi: 10.1016/S00380717(99)00014-0

Batjes, N. H. (1997). A world dataset of derived soil properties by FAO-UNESCO soil unit for global modelling. Soil Use Manag. 13, 9-16. doi: 10.1111/j.14752743.1997.tb00550.x

Bonkowski, M., Jentschke, G., and Scheu, S. (2001). Contrasting effects of microbial partners in the rhizosphere: interactions between Norway Spruce seedlings (Picea abies Karst.), mycorrhiza (Paxillus involutus (Batsch) Fr.) and naked amoebae (protozoa). Appl. Soil Ecol. 18, 193-204. doi: 10.1016/S0929-1393(01) 00165-2

Bucher, M. (2007). Functional biology of plant phosphate uptake at root and mycorrhiza interfaces. New Phytol. 173, 11-26. doi: 10.1111/j.1469-8137.2006. 01935.x
Bücking, H. (2004). Phosphate absorption and efflux of three ectomycorrhizal fungi as affected by external phosphate, cation and carbohydrate concentrations. Mycol. Res. 108, 599-609. doi: 10.1017/S0953756204009992

Bücking, H., and Heyser, W. (2001). Microautoradiographic localization of phosphate and carbohydrates in mycorrhizal roots of Populus tremula x Populus alba and the implications for transfer processes in ectomycorrhizal associations. Tree Physiol. 21, 101-107. doi: 10.1093/treephys/21.2-3.101

Bun-ya, N., Nishimura, M., Harashima, S., and Oshima, Y. (1991). The PHO84 gene of Saccharomyces cerevisiae encodes an inorganic phosphate transporter. Mol. Cell. Biol. 11, 3229-3238. doi: 10.1128/MCB.11.6.3229

Cairney, J. W. G. (2011). Ectomycorrhizal fungi: the symbiotic route to the root for phosphorus in forest soils. Plant Soil 344, 51-71. doi: 10.1007/s11104-0110731-0

Cairney, J. W. G., and Smith, S. E. (1992). Influence of intracellular phosphorus concentration on phosphate absorption by the ectomycorrhizal basidiomycete Pisolithus tinctorius. Mycol. Res. 96, 673-676. doi: 10.1016/S0953-7562(09) 80496-6

Cairney, J. W. G., and Smith, S. E. (1993a). Efflux of phosphate from the ectomycorrhizal basidiomycete Pisolithus tinctorius: general characteristics and the influence of intracellular phosphorus concentration. Mycol. Res. 97, 1261-1266. doi: 10.1016/S0953-7562(09)81295-1

Cairney, J. W. G., and Smith, S. E. (1993b). The influence of monovalent cations on efflux of phosphate from the ectomycorrhizal basidiomycete Pisolithus tinctorius. Mycol. Res. 97, 1267-1271. doi: 10.1016/S0953-7562(09)81296-3

Canales, J., Bautista, R., Label, P., Gómez-Maldonado, J., Lesur, I., Fernández-Pozo, N., et al. (2013). De novo assembly of maritime pine transcriptome: implications for forest breeding and biotechnology. Plant Biotechnol. J. 12, 286-299. doi: $10.1111 /$ pbi.12136

Casieri, L., Ait Lahmidi, N., Doidy, J., Veneault-Fourrey, C., Migeon, A., Bonneau, L., et al. (2013). Biotrophic transportome in mutualistic plant-fungal interactions. Mycorrhiza 23, 597-625. doi: 10.1007/s00572-013-0496-9

Chalot, M., Javelle, A., Blaudez, D., Lambilliote, R., Cooke, R., Sentenac, H., et al. (2002). An update on nutrient transport processes in ectomycorrhizas. Plant Soil 244, 165-175. doi: 10.1023/A:1020240709543

Clarholm, M. (1985). Interactions of bacteria, protozoa and plants leading to mineralization of soil nitrogen. Soil Biol. Biochem. 17, 181-187. doi: 10.1016/0038-0717(85)90113-0

Clarkson, D. T. (1985). Factors affecting mineral nutrient acquisition by plants. Annu. Rev. Plant Physiol. 36, 77-115. doi: 10.1146/annurev.pp.36.060185.000453

Cole, C. V., Elliott, E. T., Hunt, H. W., and Coleman, D. C. (1978). Trophic interactions in soils as they affect energy and nutrient dynamics. V. Phosphorus transformations. Microb. Ecol. 4, 381-387. doi: 10.1007/BF02013281

Coleman, D. C., Cole, C. V., Anderson, R. V., Blaha, M., Campion, M. K., Clarholm, M., et al. (1977). An analysis of rhizosphere-saprophage interactions in terrestrial ecosystems. Ecol. Bull. 25, 299-309.

Combier, J.-P., Melayah, D., Raffier, C., Gay, G., and Marmeisse, R. (2003). Agrobacterium tumefaciens-mediated transformation as a tool for insertional mutagenesis in the symbiotic ectomycorrhizal fungus Hebeloma cylindrosporum. FEMS Microbiol. Lett. 220, 141-148. doi: 10.1016/S0378-1097(03)00089-2

Darbyshire, J. F., Davidson, M. S., Chapman, S. J., and Ritche, S. (1994). Excretion of nitrogen and phosphorus by the soil ciliate Colpoda steinii when fed the soil bacterium Arthrobacter sp. Soil Biol. Biochem. 26, 1193-1199. doi: 10.1016/00380717(94)90143-0

Darrah, P. R., Tlalka, M., Ashford, A., Watkinson, S. C., and Fricker, M. D. (2006). The vacuole system is a significant intracellular pathway for longitudinal solute transport in basidiomycete Fungi. Eukaryot. Cell 5, 1111-1125. doi: 10.1128/EC.00026-06

Djigal, D., Brauman, A., Diop, T. A., Chotte, J. L., and Villenave, C. (2004). Influence of bacterial-feeding nematodes (Cephalobidae) on soil microbial communities during maize growth. Soil Biol. Biochem. 36, 323-331. doi: 10.1016/j.soilbio.2003.10.007

Finlay, R. D., and Read, D. J. (1986). The structure and function of the vegetative mycelium of ectomycorrhizal plants. II. The uptake and distribution of phosphorus by mycelial strands interconnecting host plants. New Phytol. 103, 157-165. doi: 10.1111/j.1469-8137.1986.tb00604.x

Fricker, M. D., Lee, J. A., Bebber, D. P., Tlalka, M., Hynes, J., Darrah, P. R., et al. (2008). Imaging complex nutrient dynamics in mycelial networks. J. Microsc. 231, 317-331. doi: 10.1111/j.1365-2818.2008.02043.x 
Fristedt, U., Berhe, A., Ensler, K., Norling, B., and Persson, B. L. (1996). Isolation and characterization of membrane vesicles of Saccharomyces cerevisiae harboring the high-affinity phosphate transporter. Arch. Biochem. Biophys. 330, 133-141. doi: 10.1006/abbi.1996.0235

Garcia, K., Delteil, A., Conéjéro, G., Becquer, A., Plassard, C., Sentenac, H., et al. (2014). Potassium nutrition of ectomycorrhizal Pinus pinaster: overexpression of the Hebeloma cylindrosporum HcTrk1 transporter affects the translocation of both K+ and phosphorus in the host plant. New Phytol. 201, 951-960. doi $10.1111 /$ nph. 12603

Garcia, K., Haider, M. Z., Delteil, A., Corratgé-Faillie, C., Conéjero, G., Tatry, M.-V., et al. (2013). Promoter-dependent expression of the fungal transporter HcPT1.1 under Pi shortage and its spatial localization in ectomycorrhiza. Fungal Genet. Biol. 58-59, 53-61. doi: 10.1016/j.fgb.2013.06.007

Griffiths, B. S. (1986). Mineralization of nitrogen and phosphorus by mixed cultures of the ciliate protozoan Colpoda steinii, the nematode Rhabditis sp. and the bacterium Pseudomonas fluorescens. Soil Biol. Biochem. 18, 637-641. doi 10.1016/0038-0717(86)90087-8

Harley, J. L., and Loughman, B. C. (1963). The uptake of phosphate by excised mycorrhizal roots of the beech. IX. The nature of the phosphate compounds passing into the host. New Phytol. 62, 350-359. doi: 10.1111/j.1469-8137.1963. tb06340.x

Harrison, M. J. (1999). Molecular and cellular aspects of the arbuscular mycorrhizal symbiosis. Annu. Rev. Plant Physiol. Plant Mol. Biol. 50, 361-389. doi: 10.1146/annurev.arplant.50.1.361

Harrison, M. J., Dewbre, G. R., and Liu, J. (2002). A phosphate trans- porter from Medicago truncatula involved in the acquisition of phosphate released by arbuscular mycorrhizal fungi. Plant Cell 14, 2413-2429. doi: 10.1105/tpc. 004861

Hayes, J. E., Simpson, R. J., and Richardson, A. E. (2000). The growth and phosphorus utilization of plants in sterile media when supplied with inositol hexaphosphate, glucose 1-phosphate or inorganic phosphate. Plant Soil 220, 165-174. doi: 10.1023/A:1004782324030

Herdler, S., Kreuzer, K., Scheu, S., and Bonkowski, M. (2008). Interactions between arbuscular mycorrhizal fungi (Glomus intraradices, Glomeromycota) and amoebae (Acanthamoeba castellanii, Protozoa) in the rhizosphere of rice (Oryza sativa) Soil Biol. Biochem. 40, 660-668. doi: 10.1016/j.soilbio.2007.09.026

Hinsinger, P. (2001). Bioavailability of soil inorganic P in the rhizosphere as affected by root-induced chemical changes: a review. Plant Soil 237, 173-195. doi: 10.1023/A:1013351617532

Irshad, U., Brauman, A., Villenave, C., and Plassard, C. (2012). Phosphorus acquisition from phytate depends on efficient bacterial grazing, irrespective of the mycorrhizal status of Pinus pinaster. Plant Soil 358, 155-168. doi: 10.1007/s11104-012-1161-3

Irshad, U., Villenave, C., Brauman, A., and Plassard, C. (2011). Grazing by nematodes on rhizosphere bacteria enhances nitrate and phosphorus availability to Pinus pinaster seedlings. Soil Biol. Biochem. 43, 2121-2126. doi 10.1016/j.soilbio.2011.06.015

Javot, H., Pumplin, N., and Harrison, M. J. (2007). Phosphate in the arbuscular mycorrhizal symbiosis: transport properties and regulatory roles: phosphate transport in the AM symbiosis. Plant Cell Environ. 30, 310-322. doi: 10.1111/j.1365-3040.2006.01617.x

Jorquera, M. A., Hernández, M. T., Rengel, Z., Marschner, P., and Luz Mora, M. (2008a). Isolation of culturable phosphobacteria with both phytatemineralization and phosphate-solubilization activity from the rhizosphere of plants grown in a volcanic soil. Biol. Fertil. Soils 44, 1025-1034. doi: 10.1007/s00374-008-0288-0

Jorquera, M. A., Martinez, O., Maruyama, F., Marschner, P., and Mora, M. D. L. L. (2008b). Current and future biotechnological applications of bacterial phytases and phytase-producing bacteria. Microbes Environ. 23, 182-191. doi: 10.1264/jsme2.23.182

Karandashov, V., and Bucher, M. (2005). Symbiotic phosphate transport in arbuscular mycorrhizas. Trends Plant Sci. 10, 22-29. doi: 10.1016/j.tplants.2004.12.003

Kariman, K., Barker, S. J., Jost, R., Finnegan, P. M., and Tibbett, M. (2014). A novel plant-fungus symbiosis benefits the host without forming mycorrhizal structures. New Phytol. 201, 1413-1422. doi: 10.1111/nph.12600

Kemppainen, M., Circosta, A., Tagu, D., Martin, F., and Pardo, A. G. (2005). Agrobacterium-mediated transformation of the ectomycorrhizal symbiont Laccaria bicolor S238N. Mycorrhiza 16, 19-22. doi: 10.1007/s00572-005-0008-7
Kothe, E., Muller, D., and Krause, K. (2002). Different high affinity phosphate uptake systems of ectomycorrhizal Tricholoma species in relation to substrate specificity. J. Appl. Bot. 76, 127-132.

Lambers, H., Raven, J., Shaver, G., and Smith, S. (2008). Plant nutrientacquisition strategies change with soil age. Trends Ecol. Evol. 23, 95-103. doi: 10.1016/j.tree.2007.10.008

Loth-Pereda, V., Orsini, E., Courty, P.-E., Lota, F., Kohler, A., Diss, L., et al. (2011). Structure and expression profile of the phosphate Phtl transporter gene family in mycorrhizal Populus trichocarpa. Plant Physiol. 156, 2141-2154. doi: 10.1104/pp.111.180646

Louche, J., Ali, M. A., Cloutier-Hurteau, B., Sauvage, F.-X., Quiquampoix, H., and Plassard, C. (2010). Efficiency of acid phosphatases secreted from the ectomycorrhizal fungus Hebeloma cylindrosporum to hydrolyse organic phosphorus in podzols. FEMS Microbiol. Ecol. 73, 323-335. doi: 10.1111/j.1574-6941.2010.00899.x

Mackay, J., Dean, J. F. D., Plomion, C., Peterson, D. G., Cánovas, F. M., Pavy, N., et al. (2012). Towards decoding the conifer giga-genome. Plant Mol. Biol. 80, 555-569. doi: 10.1007/s11103-012-9961-7

Maougal, R. T., Brauman, A., Plassard, C., Abadie, J., Djekoun, A., and Drevon, J. J. (2014). Bacterial capacities to mineralize phytate increase in the rhizosphereof nodulated common bean (Phaseolus vulgaris) under P deficiency. Eur. J. Soil Biol. 62, 8-14. doi: 10.1016/j.ejsobi.2014.02.006

Martin, F., Cullen, D., Hibbett, D., Pisabarro, A., Spatafora, J. W., Baker, S. E., et al. (2011). Sequencing the fungal tree of life. Lett. New Phytol. 190, 818-821. doi: 10.1111/j.1469-8137.2011.03688.x

Martinez, P., and Persson, B. (1998). Identification, cloning and charaterization of a derepressible $\mathrm{Na}+$-coupled phosphate transporter in Saccharomyces cerevisiae. Mol. Gen. Genet. 258, 628-638. doi: 10.1007/s004380050776

McElhinney, C., and Mitchell, D. T. (1993). Phosphatase activity of four ectomycorrhizal fungi found in a Sitka spruce-Japanese larch plantation in Ireland. Mycol. Res. 97, 725-732. doi: 10.1016/S0953-7562(09)80154-8

Mousain, D., Bousquet, N., and Polard, C. (1988). Comparaison des activités phosphatases? Homobasidiomycètes ectomycorhiziens en culture in vitro. Eur. J. For. Pathol. 18, 299-309. doi: 10.1111/j.1439-0329.1988.tb00217.x

Mullaney, E. J., and Ullah, A. H. (2003). The term phytase comprises several different classes of enzymes. Biochem. Biophys. Res. Commun. 312, 179-184. doi: 10.1016/j.bbrc.2003.09.176

Nehls, U., Göhringer, F., Wittulsky, S., and Dietz, S. (2010). Fungal carbohydrate support in the ectomycorrhizal symbiosis: a review. Plant Biol. 12, 292-301. doi: 10.1111/j.1438-8677.2009.00312.x

Peterson, R. L., and Bonfante, P. (1994). Comparative structure of vesiculararbuscular mycorrhizas and ectomycorrhizas. Plant Soil 159, 79-88. doi: 10.1007/BF00000097

Plassard, C., and Dell, B. (2010). Phosphorus nutrition of mycorrhizal trees. Tree Physiol. 30, 1129-1139. doi: 10.1093/treephys/tpq063

Plassard, C., Louche, J., Ali, M. A., Duchemin, M., Legname, E., and CloutierHurteau, B. (2011). Diversity in phosphorus mobilisation and uptake in ectomycorrhizal fungi. Ann. For. Sci. 68, 33-43. doi: 10.1007/s13595-0100005-7

Raboy, V. (2007). "Seed phosphorus and the development of low-phytate crops," in Inositol Phosphates: Linking Agriculture and the Environment, eds B. L. Turner, A. E. Richardson, and E. J. Mullaney (Wallingford: CAB International), 111-132.

Raghothama, K. G. (1999). Phosphate acquisition. Ann. Rev. Plant Physiol. Plant Mol. Biol. 50, 665-693. doi: 10.1146/annurev.arplant.50.1.665

Rennenberg, H., and Herschbach, C. (2013). Phosphorus nutrition of woody plants: many questions - few answers. Plant Biol. 15, 785-788. doi: 10.1111/plb.12078

Richardson, A. E., George, T. S., Jakobsen, I., Simpson, R. (2007). "Plant utilization of inositol phosphates," in Inositol Phosphates: Linking Agriculture and the Environment, eds B. L. Turner, A. E. Richardson, and E. J. Mullaney (Wallingford: CAB International), 242-260.

Richardson, A. E., and Hadobas, P. A. (1997). Soil isolates of Pseudomonas spp. that utilize inositol phosphates. Can. J. Microbiol. 43, 509-516. doi: 10.1139/m97-073 Richardson, A. E., Hadobas, P. A., and Hayes, J. E. (2000). Acid phosphomonoesterase and phytase activities of wheat (Triticum aestivum L.) roots and utilization of organic phosphorus substrates by seedlings grown in sterile culture. Plant Cell Environ. 23, 397-405. doi: 10.1046/j.1365-3040.2000.00557.x

Richardson, A. E., Hadobas, P. A., and Hayes, J. E. (2001a). Extracellular secretion of Aspergillus phytase from Arabidopsis roots enables plants to obtain phosphorus from phytate. Plant J. 25, 641-649. doi: 10.1046/j.1365-313x.2001.00998.x 
Richardson, A. E., Hadobas, P. A., and Hayes, J. E. (2001b). Utilization of phosphorus by pasture plants supplied with myo-inositol hexaphosphate is enhanced by the presence of soil micro-organisms. Plant Soil 229, 47-56. doi: 10.1023/A:1004871704173

Rodríguez-Tovar, A. V., Ruiz-Medrano, R., Herrera-Martínez, A., Barrera-Figueroa, B. E., Hidalgo-Lara, M. E., Reyes-Márquez, B. E., et al. (2005). Stable genetic transformation of the ectomycorrhizal fungus Pisolithus tinctorius. J. Microbiol. Methods 63, 45-54. doi: 10.1016/j.mimet.2005.02.016

Schachtman, D. P. (1998). Phosphorus uptake by plants: from soil to cell. Plant Physiol. 116, 447-453. doi: 10.1104/pp.116.2.447

Skinner, M. F., and Bowen, G. D. (1974). The penetration of soil by mycelial strands of ectomycorrhizal fungi. Soil Biol. Biochem. 6, 57-61. doi: 10.1016/00380717(74)90012-1

Smith, S. E., Gianinazzi-Pearson, V., Koide, R., and Cairney, J. W. G. (1994). Nutrient transport in mycorrhizas: structure, physiology and consequences for efficiency of the symbiosis. Plant Soil 159, 103-113. doi: 10.1007/BF02183090

Smith, S. E., and Read, D. J. (2008). Mycorrhizal Symbiosis, 3rd Edn. London: Academic Press.

Smith, S. E., and Smith, F. A. (2011). Roles of arbuscular mycorrhizas in plant nutrition and growth: new paradigms from cellular to ecosystem scales. Ann. Rev. Plant Biol. 62, 227-250. doi: 10.1146/annurev-arplant-042110-103846

Solaiman, M. Z., and Saito, M. (2001). Phosphate efflux from intraradical hyphae of Gigaspora margarita in vitro and its implication for phosphorus translocation. New Phytol. 151, 525-533. doi: 10.1046/j.0028-646x.2001.00182.x

Tatry, M.-V., El Kassis, E., Lambilliotte, R., Corratgé, C., van Aarle, I., Amenc, L. K., et al. (2009). Two differentially regulated phosphate transporters from the symbiotic fungus Hebeloma cylindrosporum and phosphorus acquisition by ectomycorrhizal Pinus pinaster. Plant J. 57, 1092-1102. doi: 10.1111/j.1365313X.2008.03749.x

Tibbett, M. (2002). Considerations on the use of the p-nitrophenyl phosphomonoesterase assay in the study of the phosphorus nutrition of soil borne fungi. Microbiol. Res. 157, 221-231. doi: 10.1078/0944-5013-00154

Timonen, S., Finlay, R. D., Olsson, S., and Söderström, B. (1996). Dynamics of phosphorus translocation in intact ectomycorrhizal systems: non-destructive monitoring using a $\beta$-scanner. FEMS Microbiol. Ecol. 19, 171-180. doi: 10.1111/j.1574-6941.1996.tb00210.x
Torres Aquino, M., and Plassard, C. (2004). Dynamics of ectomycorrhizal mycelial growth and $\mathrm{P}$ transfer to the host plant in response to low and high soil $\mathrm{P}$ availability. FEMS Microbiol. Ecol. 48, 149-156. doi: 10.1016/j.femsec.2004.01.008 Turner, B. L. (2008). Resource partitioning for soil phosphorus: a hypothesis. J. Ecol. 96, 698-702. doi: 10.1111/j.1365-2745.2008.01384.x

Turner, B. L., Paphazy, M. J., Haygarth, P. M., and Mckelvie, I. D. (2002). Inositol phosphates in the environment. Philos. Trans. R. Soc. Lond. B Biol. Sci. 357, 449-469. doi: 10.1098/rstb.2001.0837

Van Tichelen, K. K., and Colpaert, J. V. (2000). Kinetics of phosphate absorption by mycorrhizal and non-mycorrhizal Scots pine seedlings. Physiol. Plant. 110, 96-103. doi: 10.1034/j.1399-3054.2000.110113.x

Vance, C. P., Uhde-Stone, C., and Allan, D. L. (2003). Phosphorus acquisition and use: critical adaptations by plants for securing a nonrenewable resource. New Phytol. 157, 423-447. doi: 10.1046/j.1469-8137.2003.00695.x

Wang, J., Li, T., Wu, X., and Zhao, Z. (2014). Molecular cloning and functional analysis of a $\mathrm{H}+$-dependent phosphate transporter gene from the ectomycorrhizal fungus Boletus edulis in southwest China. Fungal Biol. 118, 453-461. doi: 10.1016/j.funbio.2014.03.003

Conflict of Interest Statement: The authors declare that the research was conducted in the absence of any commercial or financial relationships that could be construed as a potential conflict of interest.

Received: 30 July 2014; accepted: 25 September 2014; published online: 15 October 2014.

Citation: Becquer A, Trap J, Irshad U, Ali MA and Claude P (2014) From soil to plant, the journey of $P$ through trophic relationships and ectomycorrhizal association. Front. Plant Sci. 5:548. doi: 10.3389/fpls.2014.00548

This article was submitted to Plant Traffic and Transport, a section of the journal Frontiers in Plant Science.

Copyright (c) 2014 Becquer, Trap, Irshad, Ali and Claude. This is an open-access article distributed under the terms of the Creative Commons Attribution License (CC BY). The use, distribution or reproduction in other forums is permitted, provided the original author(s) or licensor are credited and that the original publication in this journal is cited, in accordance with accepted academic practice. No use, distribution or reproduction is permitted which does not comply with these terms. 